【論 文】

\title{
土壤・地下水污染の診断修復システムの開発と 不適正保管現場への適用例
}

\author{
古市徹 ${ }^{*}$. 石 井一 英 ${ }^{*}$ ・寺尾康 ${ }^{* *}$ ・森下 兼 年 ${ }^{* * *}$
}

【要 旨】廃裹物に起因する土壤・地下水污染が社会的な問題となっている。しかし，污染現場を抱え る多くの自治体は, 修復を行うための方法論がないために, 修復計画を構築するのに苦慮しているのが 現状である。よって修復対策の方法論や手順の確立が望まれているといえる。本研究では, (1) 廃棄物 に起因する土埕・地下水污染修復対策フローの提案を行った。(2)そして修復対策にスコーピングを導 入し, 浄化構想計画の位置づけとその重要性を明らかにした。(3)また污染の調查から修復代替案の提 案までを行う土譬・地下水污染診断修復支援システム（診断修復システム）の構築を行い，実不適正保 管現場にその適用を試みた。そして特に地理情報システム（GIS）を用いた污染デー夕管理システムの 有効性を明らかにした。

キーワード: 廃裹物, 土袞・地下水污染, 診断修復システム, 地理情報システム, スコーピング

\section{1.はじめに}

廃棄物の不法投棄，不適正保管，不適正処分に起因す る土境・地下水污染が社会問題となっている。修復対策 を円滑に進めるためには, 污染現場に対し, どのような 調查をどの程度行い，そしていつ，どのような修復対策 を講ずるべきかといった意思決定を，非常に多くの要因 （污染状況, 地質 - 地下水構造, 周辺環境, 修復技術, 時間, 住民, 法律, コストなど）を考虑に入れながら， 合理的に行う必要がある。

一方, 平成 9 年 6 月の廃掃法の一部改正により, (1) 産業廃衰物の減量化, リサイクルの推進, (2) 産業廃棄 物処理の信頼性と安全性の向上，(3) 不法投棄対策の強 化, (4) 原状回復措置などの総合的な産業廃棄物対策の 実施が求められるようになった には, 厚生省から全国 538 件の不適正埋立処分場が発表 され，具体的な調查, 現状把握, 場合によっては原状回 復を行うことが求められている2)。しかし，実際には廃 菓物による土垬・地下水污染の修復のための方法論がな いために, 修復対策の計画策定に苦虑している自治体, 事業者が多いのが実状である。よって廃棄物污染現場に 対する修復対策計画策定のための方法論や手順の確立が

原稿受付 1999.7. 5

* 北海道大学大学院工学研究科

**湖クボ夕

*** 東和科学

連絡先 : $=060-8628$ 札覞市北区北 13 条西 8 丁目 北海道大学大学院工学研究科桭境資源工学専攻 発暂物管理工学分野古市 徽
望まれているといえる。

これまで日本においては, 環境庁より平成 6 年に事業 系の土㙵・地下水污染に対する対策指針 ${ }^{3}$ が示され (平 成 11 年 1 月に改訂されている ${ }^{4)}$ ), 修復技術に関してる 整理されている方が，廃棄物污染現場にその指針や技術 がそのまま適用できるかは，まだ明確にはなっていない。 また米国スーパーファンドプログラムには, 調査から修 復代替案の提案までを行うプロセスである恒久措置調 查 / 実行可能性調查 ${ }^{6}$ (Remedial Investigation/Feasibility Study, 以下 RI/FS と呼ぶ）が存在し，対策に おける調查や修復技術の選択に関する事項が整理されて いるが，日本にそのシステムをそのまま適用することは そのシステムを用いるまでの前提条件が異なるために困 難である（RI/FS が適用されるのは, 恒久対策を行う と決定された污染サイトに限られており, その前に緊急 的な初期対策は終了している7)。一方, 日本では污染の 発覚時に何らかの対策が求められている)。このような 状況から, 日本においても土裹・地下水污染修復プログ ラムの構築の必要性が叫ばれているが, 具体的な方策は 末だ示されてはいない。

そこで本研究では，廃棄物に起因する土壤・地下水污 染対策の方法論や手順を確立することを最終目的とし, 本論では廃棄物に起因する土壌・地下水污染の修復対策 フローを提案する。そして修復対策にスコーピングを導 入し, 浄化構想計画の位置づけと重要性を示す。また污 染の調查から修復代替案の提案までを行う土壤・地下水 污染診断修復支援システム（以下診断修復システム）の 構築を行い, そして地理情報システム（Geographic Information System: GIS) を用いた污染データ管理シ ステムの有効性を, 実際の不適正保管現場に診断修復シ ステムを適用することにより明らかにすることを目的と した。 


\section{2. 廃棄物に起因する土壇・地下水污染の対策 の考え方}

\section{1 悠復対策フロー}

廃裹物に起因する土境・地下水污染対策は，これまで 比較的多く報告されている事業系の污染とは次の 3 つの 点で異なると考えられる。すなわち, (1) 山間や谷間等 の複雑な地形・地質を有する場に存在すること, (2) 多 種多様な污染物質を含んだ複合的な污染であること, (3) 事業者の責任能力がそしい場合が多い。また，污染され ている媒体も複数 (廃棄物, 表流水, 土壤, 地下水, 大 気）存在し, どのようなプロセスで修復対策を行うべき か判断に苦慮する点であある。このような廃棄物に起因 する土䗙・地下水污染に対する修復対策フローを Fig. 1 に示す。これはU.S. EPA スーパーファンドプログ ラムの $\mathrm{RI} / \mathrm{FS}^{6}$ ) を参考に作成したものである。以下に このフローの説明を行う。

1）まずスコーピング（Fig. 1 の網掛け部分, 2.2 節 で後述する）において，初期現場調查（既存資料の 収集, 目視レベルからの調查, 分析調查）を行うこ とにより污染源である廃棄物そのあのの周辺環境に 対する污染ポテンシャルを評価し, 緊急度の高い場 合には初期対策を行う。また総合的な污染修復対策 を行うための関連情報（法律, 住民の意見等）を広 く収集した上で，Fig. 1 に示す浄化対策全体を見渡 し, 対策の期間・コストなどの制約, 対策間の時間 的つながり, 対策の優先順位等を考慮し, 浄化構想 計画を構築する。净化構想計画では, 以下に定義さ れる初期対策，応急対策，恒久対策それぞれの段階 で行うべき対策の目的，作業内容，および調查計画 等を決定する。

初期対策：初期調查によってリスクが高いと判断さ れたものに対するもの（污染源の撤去など）。人の 健康や環境に影響をおよばす危険があるすのに対 するもの（住民への告知, 敷地外への流出防止, 飲料制限)

応急対策：污染が拡大する恐れのあるあのに対する あの（初期対策で行われなかった対策, 流出・拡 散防止対策など）

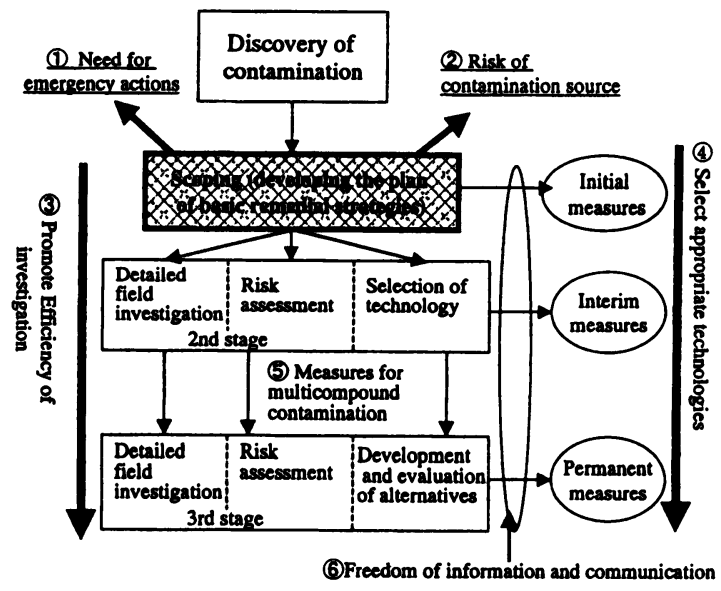

Fig. 1 Flow chart of countermeasures for soil and groundwater contamination caused by waste materials
恒久対策：応急対策時に行えなかった媒体の修復, 跡地利用まで考虑に入れた対策

実際の作業では，このように明確に対策を分ける ことは困難であると思われるが, 全修復作業を各段 階に分けさらに各対策の特徴付けを行うことによっ て全修復対策における各対策の位置づけを明確にす ることが重要である。

2 ）次の第 2 段階では, 净化構想計画にしたがい現場 調查を行うことによって污染状況を把握し，リスク 評価を行う。そして応急対策を実施するための技術 選択を行う。この際, 効率的な調查を行うために, 修復技術選択（スクリーニングあ含む）を同時に行 い, それぞれの段階で想定されている対策に対応し た調查を行う必要がある。これまでは調查を行って から修復対策の検討を行っており，再度調查を絽り 返す場合も少なくなかった。調查を効率的に行うた めには, 目的としての対策のレベルに応じてどの程 度の調查をしておく必要があるかといった逆からの 検討あ必要である。すなわち污染現場の修復対策を 実施する上で，予め対策の目的を定め，そして想定 される修復技術を絞り込んでから調査計画を構築す ることで, 調查の目的が明確になり調查の後戻りを 防止し, 結果として調查の効率性を高めることがで きると考えている。

3）第 3 段階では，恒久対策を目的とした調査，リス クアセスメントを行い, 恒久対策代替案を構築し, 評価を行う。この際, 2 段階目同様, 予備的な代替 案を予め構筑しておき, 代替案を評価するために必 要な調查を行うことが重要である。

4）各段階での対策の実施にあたっては, 住民とのコ ミュニケーションを行うこと。ただし,コミュニ ケーション技法については本論文では扱わない。

\section{2 スコーピング}

スコーピングとは, Fig. 1 に示すように污染修復対 策における構想計画に相当し，污染現場の污染状況や対 策を進める上での問題点を既存情報および初期現場調査 により的確に把握・整理し, 污染の緊急度, 対策期間, コスト, 法律等を考虑して, 基本的な対策の方針（目 的）と調査計画を構築するプロセスであると定義できる。 つまり，スコーピングを行うことによって，その污染サ イトにとって最も重要かつ㹂急的な課題を明確にするこ とができ，短期的・中長期的それぞれの時間軸に応じて どのような対策が存在するか，そしてそのつながりや連 携について予め試行錯誤的に検討することができる。こ のように修復対策の全体像を把握することにより, 修復 作業の全体の見通しとその効果について議会や住民に予 め説明することが可能となる。

Fig. 2 にスコーピングの手順とスコーピング時に考 慮すべき事項を示す。まず既存情報収集・整理, 初期現 場調查を行い，必要であれば初期対策を実施する。さら にそれ以降の対策に適用可能な技術に関する情報を収集 し, 净化構想計画を構築する。浄化構想計画の内容は,

(1) 浄化方針（浄化目標, 期間, コスト等の前提条件 の予備的决定, 各段階での目的と作業内容）

（2）概略的な調查計画（湘定範囲，位置，サンプリン グ媒体, 測定污染物質, サンプリング・分析方法）

（3）予備的な応急対策の代替案

(4) 適用する法律

（5）社会（住民）との連絡手段, 合意形成，情報開示 に関する計画

である。 


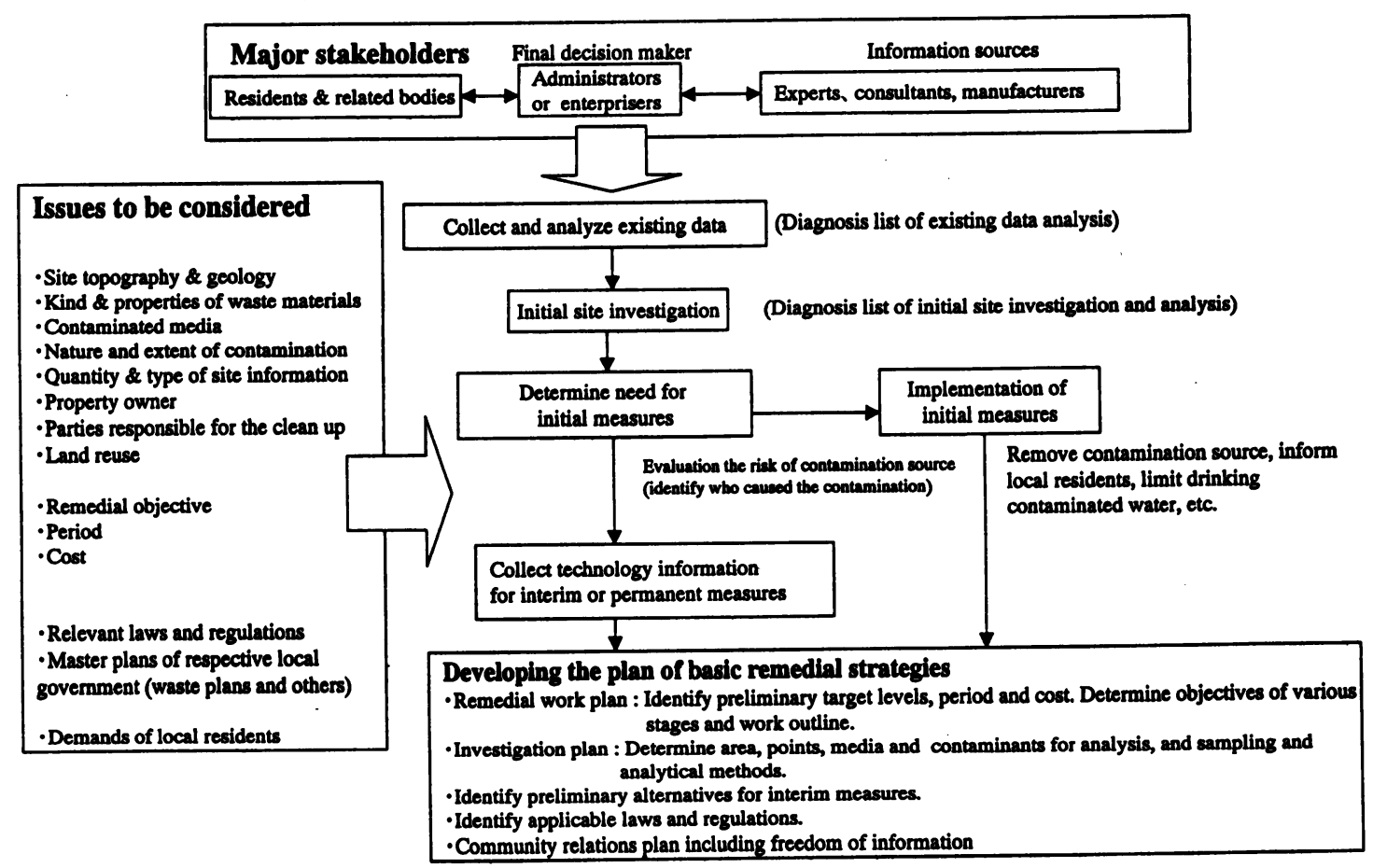

Fig. 2 Procedure of Scoping

スコーピングを行い, 浄化構想計画を構築するために は, 初期現場調查において最低限概略的な污染範囲, 污 染濃度, 污染の原因が判明していなければならない。さ らにスコーピングは, 対策のはじめのみに行われるので はなく, 污染状況の変化, 調查の進展による計画の見直 し，変更に応じて随時行われるべきである。

2. 3 他の分野におけるスコーピングとの䢖い

スーパーファンドプログラムの RI/FS中にあ「ス コーピング」という言葉が存在する ${ }^{6)}$ 。 スーパーファン ドプログラムの手順は, EPA により潜在的な有害廃裹 物所在地とされたサイトは, 包括的環境対処・補偵・責 任情報システム（CERCLIS：Comprehensive Environmental Response, Compensation and Liability Information System) に登録され, 制度としてデー夕 ベース化されている。そして, まず予備調查（PA：Preliminary Assessment), 現地調查 (SI : Site Investigation）が行われ，その段階で必要ならば撤去作業等の緊 急的な対策が行われる。それから危険度評価システム (HRS: Hazard Ranking System) によって，恒久対 策が必要であると判断されたサイトに対して RI/FS が 行われる。つまり，RI/FSにおけるスコーピングは， 既に PA PSI の段階で緊急的な対策が終了し，修復へ の動機付けがされた，すなわち修復を前提としたサイト に対して行われるあのであるから, 緊急度の判断や緊急 的な対策の実施，そして修復への動機付けは含んでいな い。それに対して, 日本では制度として污染サイトの登 録はされておらず, 偶然発見されることが多い。そのた め, 本研究での日本版としてのスコーピングは, 污染修 復への動機付け，緊急度の判断や初期対策の判断を含ん だあのにならざるをえない。この点が大きな違いである。

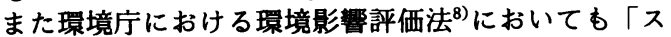

コーピング」という言葉が用いられている。環境影響評 価法のスコーピングは，事業の環境への影䍂を評価する 目的で行われるのに対して, 本研究のスコーピングは污 染サイトの修復を目的としている。したがって, 対象と する目的が異なっているといえる。

\section{3. 診断修復システムの構築}

\section{1 診断峯復システムの概要}

本研究で提案する診断修復システムとは, 污染発覚前 の污染診断段階および污染発覚後の調查段階から修復対 策代替案を提示するまでの段階を支援するシステムのこ とである ${ }^{9)}$ 。

診断修復システムの主たる要素と要素間のつながりに ついて Fig. 3 に示す。「診断カルテ」は, 調查のチェッ ク機能（調查すべき項目の提示）と履歴保管機能（調 查・対策に関する情報を保管) を有するすのである。そ して収集された調查結果（目視調查による画像データや 分析による測定結果等）は,「GIS 污染データ管理シス テム」により一元的に管理が行われる。また「解析 / 評価」は, 污染物質移動予测, 修復効果予測等を行うシ ミュレーション部分であり，その結果を GIS 上で表示 させることができる。さらにこれら解析および調査結果 を用いて, 修復技術の選択, 代替案の構築・評価を「修 復方法の設計」の部分で行う。

これまでは調查手法, 解析手法, 修復技術等個々の要 素がそれぞれ開発・改善されてきたが，本研究において はそれぞれの要素を有機的に結びつけ全体のシステムと して構築し，またユーザーインターフェイスとして GIS を採用した点が特徴である。

本研究では, 診断カルテ, GIS 污染データ管理システ ム, 修復方法の設計に関して以下に提案を行う。 


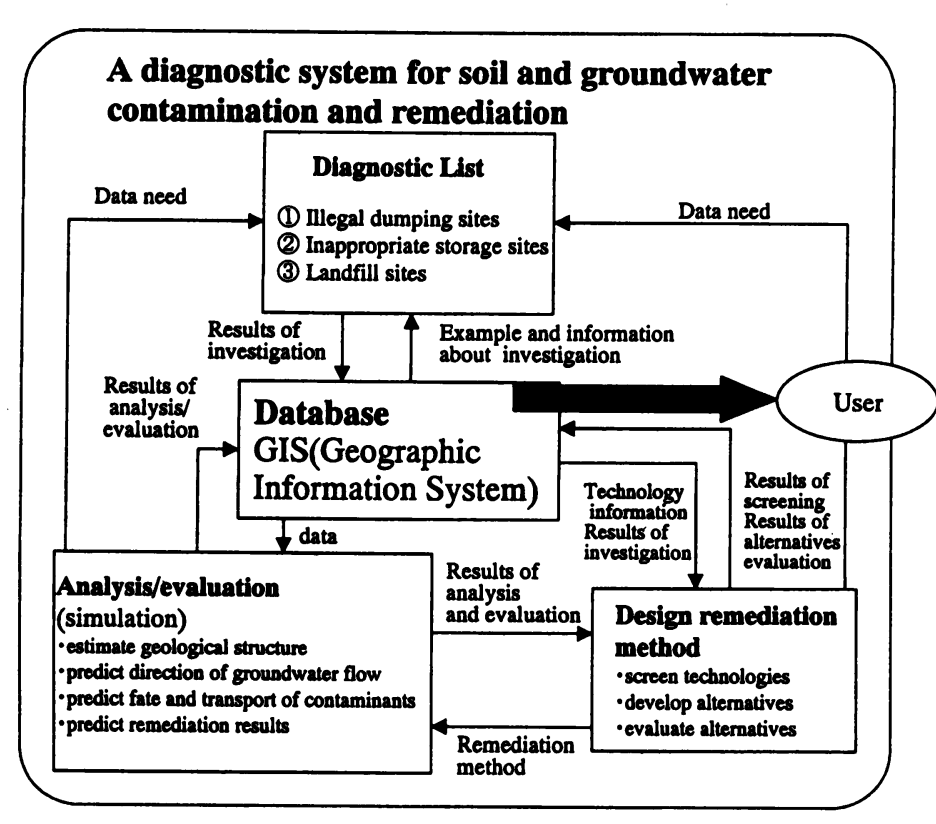

Fig. 3 Composition of a diagnostic system
管理すること, (2) 多くのデータから 目的に応じ検索・抽出を行い, 地図情 報とともに画面上に表示すること，(3) データが十分ある場合には, 内挿手法 等を用いてコンターを描くこと, (4) さらにシミュレーション部分とのデー タのやりとりや, 解析結果を表示する など, 診断修復システム全体のュー ザーインターフェイスとして, ユー ザーに污染状況や修復効果をグラフィ カルな表現により伝達する機能を有す る。 4 章において本システムの表示例 を示す。

\section{4 修復方法の設計一腹プロセス の選択手順の概略}

修復方法の設計とは，対象サイトに 対して適用できる要素技術のスクリー ニングを行い，これらの要素技術を組 み合わせて代替案を構築し，ある評価 基準により代替案を選択することであ るが，これまでサイトに適した技術を 選択する方法論は存在しなかった。そ こで, 多種多様な修復プロセスの中か ら適切なプロセス選択を客観的かつシ ステマティックに行うための手順を構 築する必要があると考えた。

\section{2 診断カルテの提案}

不適正保管現場を対象とした場合の既存情報収集カル テ (Table 1) および初期現場調查カルテ (Table 2) を示す。Fig. 1 に示したスコーピング段階では, 既存 情報と目視調查レベルにおいて, 大気, 表流水, 土埣, 地下水媒体中における污染物質移動形態をサイトの地形, 地質, 水文状況などから概略的に把握すること，そして サンプリングと分析により, 概略的な污染範囲, 濃度, 污染原因を把握し緊急度の高い部分を抽出することが重 要である。このような調查を行うことにより, 污染源か ら受容者までの污染物質輸送経路を特定することができ る。

$\mathrm{RI} / \mathrm{FS}^{6)}$ では, スコーピング段階の污染源から受容 者までの污染物質輸送経路の概略を示すサイト特有のモ デルのことを, conceptual model (概念モデル) と呼 んでいる。污染の概況把握とその污染物質がおよぼす影 響を検討するための図，あるいはフローチャートである。 RI/FSにおいても, 概念モデルは, 污染物質の輸送経 路を特定するのに重要であるとされている。

また初期現場調查段階で重要な要素の一つとして, 住 民への聞き取り調查があげられる。U. S. EPA あ $\mathrm{CRP}^{10)}$ (Community Relation Plan) において Community Interview として取り上げている。聞き取り調 査により今後の浄化対策においてどのような対策を優先 することを望んでいるのかおらかじめ調べ, 今後の住民 とのコミュニケーションの行い方について净化構想計画 では明文化する必要があると考えている。

\section{3 GIS 污染データ管理システム}

GIS は様々な情報，あるいは既存のデータベースの情 報を地図上の点や図形の属性とリンクさせることができ るので, ユーザーは一枚の地図上に目的とするデー夕を 場所と関連づけて表示させることが可能となる。

そして GIS 派染データ管理システムの役割は, (1) 診 断カルテにまとめられた多岐にわたるデー夕を一元的に
Fig. 4 に不適正保管現場を対象とした場合の, 修復 プロセス選択手順と修復プロセスの選択例を示す。図は 価基準，選択された対策，スクリーニングされた技術を 示している。スコーピング段階では，まず浄化構想計画 における各段階の作業目標・内容にしたがって, 初期対 策の内容を決定し，応急，恒久対策の作業内容に適合す る技術のスクリーニングを行う。そして応急対策時には 応急対策の内容を決定し, 恒久対策のための技術スク リーニングを行うというように，各対策を行う前の段階 までに技術のスクリーニングを行い，予備的な代替案を 構築しておくことが本手順のポイントである。

\section{4. 診断修復システムの実污染現場への適用例} (Fig. 1のスコーピング段階を対象)

\section{1 対象污染サイトの概況}

次に, 実際の污染現場を対象に診断修復システムの適 用を試みる。本研究で対象とした污染現場サイトは, G 5 参照)。昭和 60 年頃より事業者所有の敷地内に, 有機 塩素系溶剤, 廃油が含まれたドラム缶が不適正に積み重 ねられ保管されてきた。平成 8 年, 廃棄物研究財団が中 心となり，F県および $\mathrm{G}$ 市の協力を得て調查が行われ た。溶出試験により内容物は複数の有害物質が含まれて おり, 多くの腐食したドラム缶から内容物が流出した形 跡が見られた。また敷地内の土堹, 表流水, 地下水とも に数種の有機塩素化合物が検出された。そして平成 10 いう形で平成 10 年 11 月からドラム缶撤去作業および, 表流水の排水溝の整備, 水処理施設建設工事が開始され た。

以下に，スコーピング段階において，このような対策 を講ずるに至った背景と考え方を, 診断修復システムを 本サイトに適用することにより示す。 左から, 污染修復対策の進行, 代替案を決定する際の評 市内に存在するドラム缶の不適正保管現場である（Fig. 年に, 事業者への措置命令が下され, 県による代執行と 
Table 1 Diagnostic list (checking list) for exsiting data analysis

\begin{tabular}{|c|c|c|c|}
\hline Objective & $\begin{array}{l}\text { Collect and } \\
\text { pathways and }\end{array}$ & $\begin{array}{l}\text { analyze existing data to identify potential } \\
\text { d routes, and potential receptors }\end{array}$ & contamination sources, potential exposure \\
\hline Essential factor & Class & Item & Entry example \\
\hline \multirow{8}{*}{$\begin{array}{l}\text { Contamination } \\
\text { source }\end{array}$} & General & $\begin{array}{l}\text { Site name and address } \\
\text { Property owner and contact }\end{array}$ & $\begin{array}{l}\text { Inappropriate storage site at G City } \\
\text { person D }\end{array}$ \\
\hline & \multirow{3}{*}{$\begin{array}{l}\text { Place of } \\
\text { storage }\end{array}$} & $\begin{array}{l}\text { Location } \\
\text { (a mountainous region, a rabine, and others) }\end{array}$ & $\begin{array}{l}\text { Man-made changes resulting in many levels } \\
\text { of flat lands. }\end{array}$ \\
\hline & & Surface area & $25,000 \mathrm{~m}^{2}$ \\
\hline & & $\begin{array}{l}\begin{array}{l}\text { Other treatment facilities and available } \\
\text { information }\end{array} \\
\end{array}$ & $\begin{array}{l}\text { incineration facility, batch furnace, considerable } \\
\text { deterioration }\end{array}$ \\
\hline & \multirow{4}{*}{$\begin{array}{l}\text { Material } \\
\text { stored }\end{array}$} & Type and content and Quantity & drums, oil-based, organic solvent, large quantities \\
\hline & & \begin{tabular}{|l|} 
Period of storage \\
\end{tabular} & since 1985 \\
\hline & & \begin{tabular}{|l|} 
Storage conditions \\
\end{tabular} & stock piled and corroded \\
\hline & & Origin and Process of waste generation & unknown \\
\hline \multirow{6}{*}{$\begin{array}{l}\text { Environment } \\
\text { around the } \\
\text { site }\end{array}$} & \begin{tabular}{|l|} 
Past records \\
\end{tabular} & \begin{tabular}{|l|} 
Investigation records and contents \\
Geographical features, rivers, mars \\
\end{tabular} & \begin{tabular}{|l|} 
none \\
refer to $\mathrm{m}$ \\
\end{tabular} \\
\hline & \begin{tabular}{|l|} 
Topography \\
Geology
\end{tabular} & $\begin{array}{l}\text { Geographical features, rivers, marsnes } \\
\text { patterns }\end{array}$ & NS \\
\hline & Hydrology & \begin{tabular}{|l|} 
Precipitation amount \\
Water balance (inflow and outflow) \\
\end{tabular} & annual average, $1,500 \mathrm{~mm}$ \\
\hline & \begin{tabular}{|l|} 
Groundwater \\
\end{tabular} & \begin{tabular}{|l} 
Water balance (inflow and outflow) \\
Direction of flow and slope \\
\end{tabular} & $1 / 3$ emission, $1 / 3$ effluent, $1 / 3$ ground percolation \\
\hline & \multirow{2}{*}{ Climate } & \begin{tabular}{|l|} 
Direction of flow and slope \\
Temperature \\
\end{tabular} & from mountain to River C \\
\hline & & \begin{tabular}{|l|} 
Temperature \\
Wind direction and strength \\
\end{tabular} & \\
\hline \multirow{9}{*}{$\begin{array}{l}\text { Land use in the } \\
\text { surrounding } \\
\text { area }\end{array}$} & \multirow{3}{*}{ Residential } & \begin{tabular}{|l|l} 
Wind direction and strength \\
Population distribution, number of households
\end{tabular} & There is only one person near the site. \\
\hline & & $\begin{array}{l}\text { Distribution and current use of wells and } \\
\text { water intake }\end{array}$ & $\begin{array}{l}\text { There is a water intake } 2 \mathrm{~km} \text { downstream } \\
\text { River C }\end{array}$ \\
\hline & & Special emphasized mutual agreement & freedom of information \\
\hline & \multirow{4}{*}{ Industrial } & \begin{tabular}{|l|} 
Previous problems, name of organizations \\
Crop production? \\
\end{tabular} & River C Protection Assoc. \\
\hline & & \begin{tabular}{|l|} 
Crop production? \\
Livestock production? Fishing? \\
\end{tabular} & on the opposite site of River C \\
\hline & & \begin{tabular}{|l|} 
Livestock production? Fishing? \\
Factories or offices? \\
\end{tabular} & none, none \\
\hline & & \begin{tabular}{|l|} 
Factories or offices? \\
Possibility of other contamination source \\
\end{tabular} & none \\
\hline & \multirow{2}{*}{ Others } & \begin{tabular}{|l|} 
Possibility of other contamination source \\
Parks, recreational facilities available? \\
\end{tabular} & none \\
\hline & & \begin{tabular}{|l|} 
Parks, recreational facilities available? \\
Endangered flora and fauna present? \\
\end{tabular} & none \\
\hline \multirow{2}{*}{\multicolumn{3}{|c|}{ Relevant laws }} & \\
\hline \multirow{3}{*}{ Evaluation } & \multirow{3}{*}{$\begin{array}{l}\text { Conceptual } \\
\text { model }\end{array}$} & & \begin{tabular}{|l} 
Environmental standard, and Effluent standard \\
drums and contents
\end{tabular} \\
\hline & & \begin{tabular}{|l} 
Potential transport pathways \\
\end{tabular} & \begin{tabular}{|l|} 
drums and contents \\
$\begin{array}{l}\text { drums } \rightarrow \text { surface water } \rightarrow \text { River } C \\
\text { drums } \rightarrow \text { soil } \rightarrow \text { ground water/drums } \rightarrow \text { atmosphere }\end{array}$ \\
\end{tabular} \\
\hline & & Potential exposure pathways and routes & $\begin{array}{l}\text { atmosphere } \rightarrow \text { breathing/ground water } \rightarrow \text { drinking } \\
\text { River } \mathrm{C} \rightarrow \text { drinking water/soil } \rightarrow \text { contact }\end{array}$ \\
\hline & \multirow{2}{*}{\multicolumn{3}{|c|}{$\begin{array}{l}\text { Detailed data on topography, geology and groundwater is necessary. Further data on quantity of drums } \\
\text { and contents is necessary. } \\
\text { Measuring contaminant concentration in surface water, soil and groundwater is required. }\end{array}$}} \\
\hline Plan & & & \\
\hline
\end{tabular}

\section{2 GIS 污染デー夕管理システムの使用例}

まず先に示した Table 1，2 に当該污染現場における 既存情報収集カルテ, 初期現場調查カルテの記入例を示 しておく。そして各サンプリング地点の位置, 測定値, 現場画像情報等をシステムに入力する。

まずサイトの地理，地形情報と污染現場の概略をまと める。Fig. 5 は測量によって得られた污染現場地図， ドラム缶が保管されている領域，画像デー夕として斜線 領域のドラム缶の保管状況を示している（地下水調査の 結果あ示しているが後で説明する)。さらにボーリング 調查（8本）の柱状図と広域的な地形・地質条件により 推測された地形断面図および地質構造を示したあのであ る（地質構造はここでは言及しない）。本サイトはFig. 5 に示すように南東加ら北西にかけて傾斜しており, 切 り土や盛土によって数段の平坦地に造成されている (B-B' 断面図を参照)。またサイトの北西には, 未耕作 の水田を境にして北東から南西に流れるC川が隣接し ている。ドラム缶の保管状況は極めて悪く, 最大で 7 段 重ねられていた。また内容物が流出していることから, まずドラム缶撤去を行う必要性が示唆された。
次にスコーピング段階では，污染源（この場合ドラム 缶）について, その内容物, 腐食状態, 保管状態につい てさらに詳しく調べる必要がある。Fig. 6 は, ドラム 缶内容物を直接サンプリングし, 溶出試験を行った結果 （物質 T）を表したあので，サンプリング地点（白丸） および溶出濃度を円の大きさで示し，さらに溶出値が大 きかった箇所の画像を表したものである。これより，サ ンプリング地点のほとんどで物質 $\mathrm{T} か ゙$ 検出され, ドラ ム缶から内容物が流出していることから容易に表流水污 染や污染物質が地下浸透する可能性のあることがわかる。 このように，実際の測定値とその捕捉情報として画像 データを同時に示すことで, 污染現場の緊急度を視覚的 に伝達することができる。

Fig. 7 は，表流水の流路および分析結果を示してい る。この図からわかるように敷地内の多くの点で, 污染 物質が基準を越えて検出されていることがわかる。した がって, 台風や豪雨による災害時に大量の污染物質が敷 地外へ流出する可能性が䯚念される。C川下流には農業 用水の取水口が存在し敷地外に污染表流水が流出すると 被害が大きくなる。これに対して表流水の流出防止対策 
Table 2 Diagnostic list (checking list) for initial site investigation and analysis

\begin{tabular}{|c|c|c|c|c|}
\hline \multirow{2}{*}{\begin{tabular}{|l|} 
Objective \\
Essential factor \\
\end{tabular}} & \multicolumn{4}{|c|}{$\begin{array}{l}\text { Acquire additional information. Confirm existing data. } \\
\text { Determine if the contaminated site have any effects on the surrounding population and environment. Confirm whether there } \\
\text { is a critical point or not. }\end{array}$} \\
\hline & Method & Class & Item & Entry example \\
\hline \multirow{17}{*}{$\begin{array}{l}\text { contamination } \\
\text { source and the } \\
\text { site }\end{array}$} & \multirow[t]{11}{*}{ Observation } & \multirow[t]{5}{*}{ Waste } & Type and storage conditions & $\begin{array}{l}\text { piles of drums and containers. Contains are oil and } \\
\text { organic solvents, and drums are rusted and leaky. }\end{array}$ \\
\hline & & & Container label & toxic, no label, poisonous and so on \\
\hline & & & Type of containers & almost drums and containers \\
\hline & & & \begin{tabular}{|l|} 
Percussion examination \\
\end{tabular} & almost solid? \\
\hline & & & Offensive smell & oil-based, organic solvent odor, peculiar smell \\
\hline & & \multirow[t]{2}{*}{ Leachate } & Are there any leaching? & yes \\
\hline & & & Color & brown, light brown, and green \\
\hline & & Quantity & Number of containers and weight & about 55,000 \\
\hline & & \multirow[t]{2}{*}{ Condition } & Extent of corrosion & quite serious! Many locations can not be identified. \\
\hline & & & Storage area & refer to map \\
\hline & & $\begin{array}{l}\text { Highly contaminated } \\
\text { areas Critical point } \\
\text { (Hot spot) }\end{array}$ & $\begin{array}{l}\text { Are there any critical points? } \\
\text { Where are they? }\end{array}$ & $\begin{array}{l}\text { ponding besides incinerator, oil accumulation } \\
\text { between block no. } \mathrm{X} \text { and } \mathrm{Y}\end{array}$ \\
\hline & \multirow{6}{*}{$\begin{array}{l}\text { Sampling } \\
\text { and analysis }\end{array}$} & Waste & \multirow{4}{*}{$\begin{array}{l}\text { Chemical constituent analysis and } \\
\text { leaching test }\end{array}$} & refer to leaching test results \\
\hline & & \begin{tabular}{|l|}
$\begin{array}{l}\text { Leachate, } \\
\text { surface water }\end{array}$ \\
\end{tabular} & & refer to surface water analysis results \\
\hline & & \begin{tabular}{|l|} 
Surface soil and \\
deep soil
\end{tabular} & & refer to soil analysis results \\
\hline & & Atmosphere & & \\
\hline & & Geology & properties and structures & refer to boring survey results \\
\hline & & Groundwater & groundwater levels and quality & refer to boring survey and analysis results \\
\hline \multirow[t]{6}{*}{$\begin{array}{l}\text { Environment } \\
\text { around the site }\end{array}$} & \multirow[t]{5}{*}{ Observation } & $\begin{array}{l}\text { Topography and } \\
\text { geology }\end{array}$ & $\begin{array}{l}\text { Additional topographical and geological } \\
\text { data }\end{array}$ & \\
\hline & & Surface soil & Color, vegetation wilting & no appreciable change \\
\hline & & \multirow{3}{*}{$\begin{array}{l}\text { Rivers, Marshes } \\
\text { Water puddling }\end{array}$} & Color, odor & no appreciable change \\
\hline & & & Particulate matter, presence of oil & no appreciable change \\
\hline & & & Any effects on fish \& small animals? & none \\
\hline & $\begin{array}{l}\text { Sampling } \\
\text { and analysis }\end{array}$ & \begin{tabular}{|l|} 
Surface soil \\
Surface water \\
Rivers and Marshes \\
Groundwater \\
\end{tabular} & $\begin{array}{l}\text { Comparing with standards } \\
\text { and background values }\end{array}$ & $\begin{array}{l}\text { surface soil : no measurement } \\
\text { surface water: not contaminated } \\
\text { rivers and marshes: not contaminated } \\
\text { groundwater and drinking wells : not contaminated }\end{array}$ \\
\hline \multirow{8}{*}{$\begin{array}{l}\text { Land use in the } \\
\text { surrounding } \\
\text { area }\end{array}$} & \multirow{7}{*}{ Hearings } & Local residents & Health condition & not effected \\
\hline & & & Well water quality & Person D always boils before drinking \\
\hline & & Crop production & Any effects on crops? & not effected \\
\hline & & \begin{tabular}{|l|} 
Livestock production \\
\end{tabular} & Effects on meat \& milk products? & none \\
\hline & & Fishing & Effects on fish? & none \\
\hline & & Factories \& offices & History and use of chemicals & none \\
\hline & & public agreement & Any questions about the site and demands & Drums must be removed immediately. \\
\hline & \begin{tabular}{|l|}
$\begin{array}{l}\text { Sampling \& } \\
\text { analysis }\end{array}$ \\
\end{tabular} & Foods & Constituent analysis & no measurement \\
\hline \multirow[t]{7}{*}{ Evaluation } & \multirow{6}{*}{$\begin{array}{l}\text { Observation } \\
\text { and analysis } \\
\text { results }\end{array}$} & \multicolumn{2}{|c|}{ Total evaluation of waste material (risk of contamination source) } & extremely high \\
\hline & & \multicolumn{2}{|c|}{$\begin{array}{l}\text { Transport pathways of the contaminants and extent of the } \\
\text { conmtamination }\end{array}$} & $\begin{array}{l}\text { drums } \rightarrow \text { surface water } \rightarrow \text { River C } \\
\text { Groundwater within the site is contaminated. } \\
\text { Soil is contaminated to about } 2 \mathrm{~m} \text { deep/ }\end{array}$ \\
\hline & & \multicolumn{2}{|l|}{ Off-site contamination } & $\begin{array}{l}\text { There is possibility that off-site groundwater } \\
\text { and surface water are contaminated. }\end{array}$ \\
\hline & & \multicolumn{2}{|c|}{ Are drinking wells contaminated? } & only one, and only person D drinks \\
\hline & & \multicolumn{2}{|c|}{$\begin{array}{l}\text { Effects on surrounding environment (any effects on human } \\
\text { and plants \& animals?) }\end{array}$} & no \\
\hline & & \multicolumn{2}{|c|}{$\begin{array}{l}\text { Relationship between contaminant and the local environment } \\
\text { (compare with background values) }\end{array}$} & $\begin{array}{l}\text { Local environment is not contaminated. But } \\
\text { groudwater, soil, and surface water within the site } \\
\text { are contaminated by the inappropriate storage. }\end{array}$ \\
\hline & \multicolumn{3}{|c|}{ Total decision on urgency } & $\begin{array}{l}\text { Highly urgent measures on drums and surface } \\
\text { water are necessary. }\end{array}$ \\
\hline \multirow[t]{5}{*}{ Plan } & Is removing $\mathrm{c}$ & ontamination source & needed? & yes \\
\hline & Are any meas & sures to prevent off-si & ite contamination needed? & $\begin{array}{l}\begin{array}{l}\text { Urgent measures against surface water and } \\
\text { preventing groundwater contamination are needed. }\end{array} \\
\end{array}$ \\
\hline & Is restricting & drinking contaminate & ed water needed? & yes \\
\hline & Is restricting & intake of food and fis & sh products needed? & no \\
\hline & Is reinvestiga & tion needed? If so, wh & hat are the objectives? & $\begin{array}{l}\text { Understanding of geological structure and } \\
\text { groundwater with monitoring and pumping } \\
\text { test is required. }\end{array}$ \\
\hline
\end{tabular}


Scoping (developing the plan of basic remedial strategies)

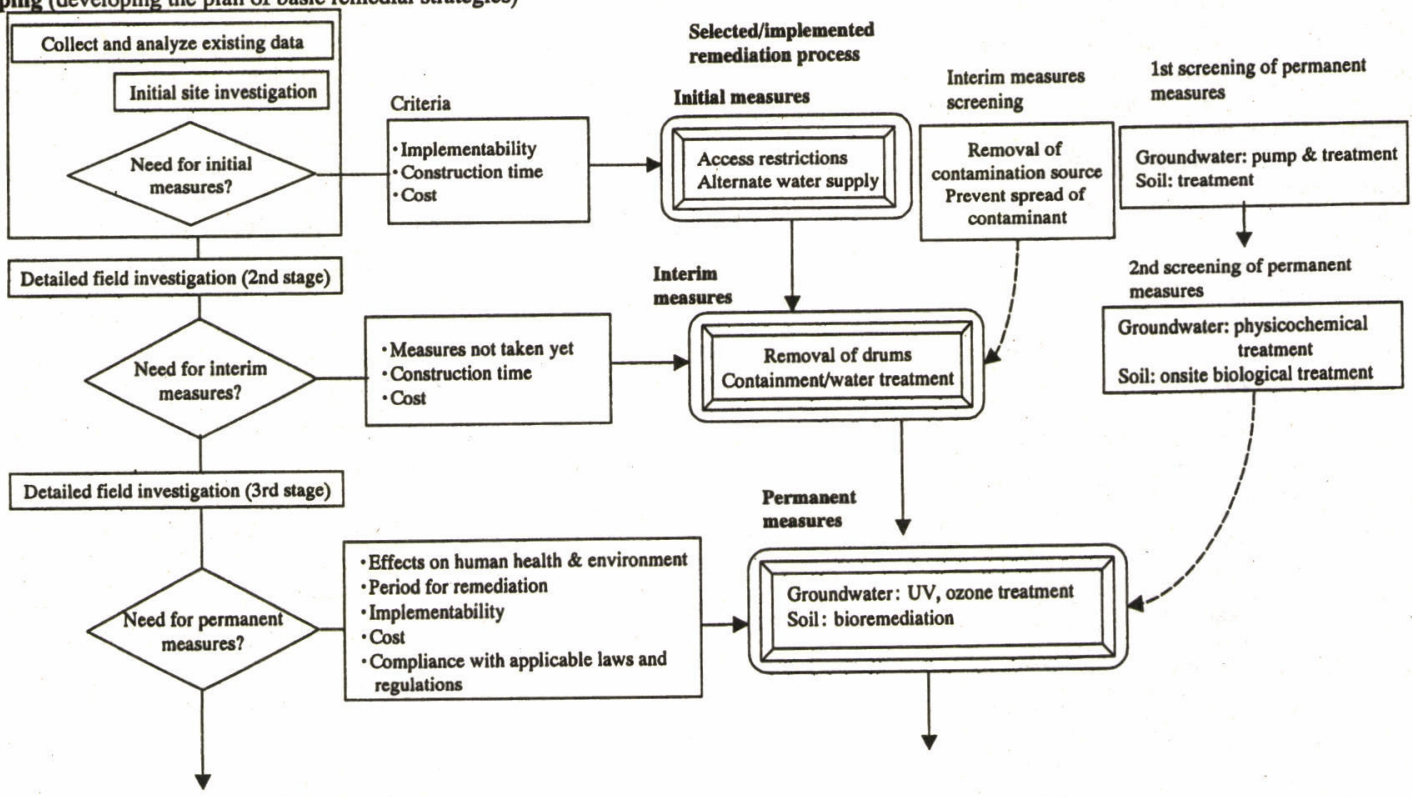

Fig. 4 Procedure and example of remedial process selection (for inappropriate storage sites)

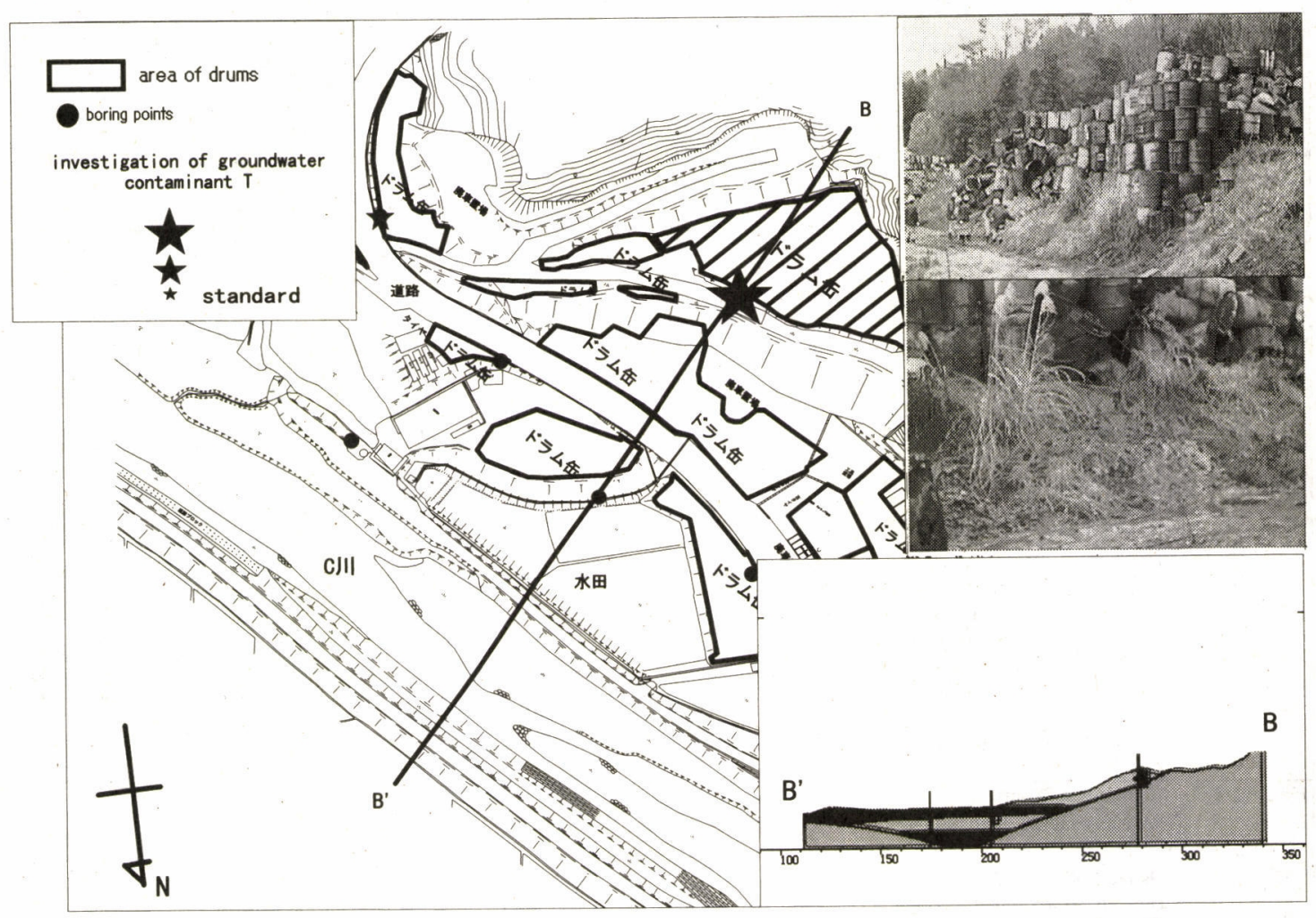

This figure shows the contaminated site map, on which area of drums stored inappropriately, pictures of the drums, B-B' section and results of groundwater analysis (contaminant T) are showed.

Fig. 5 A demonstration of GIS in diagnostic system 


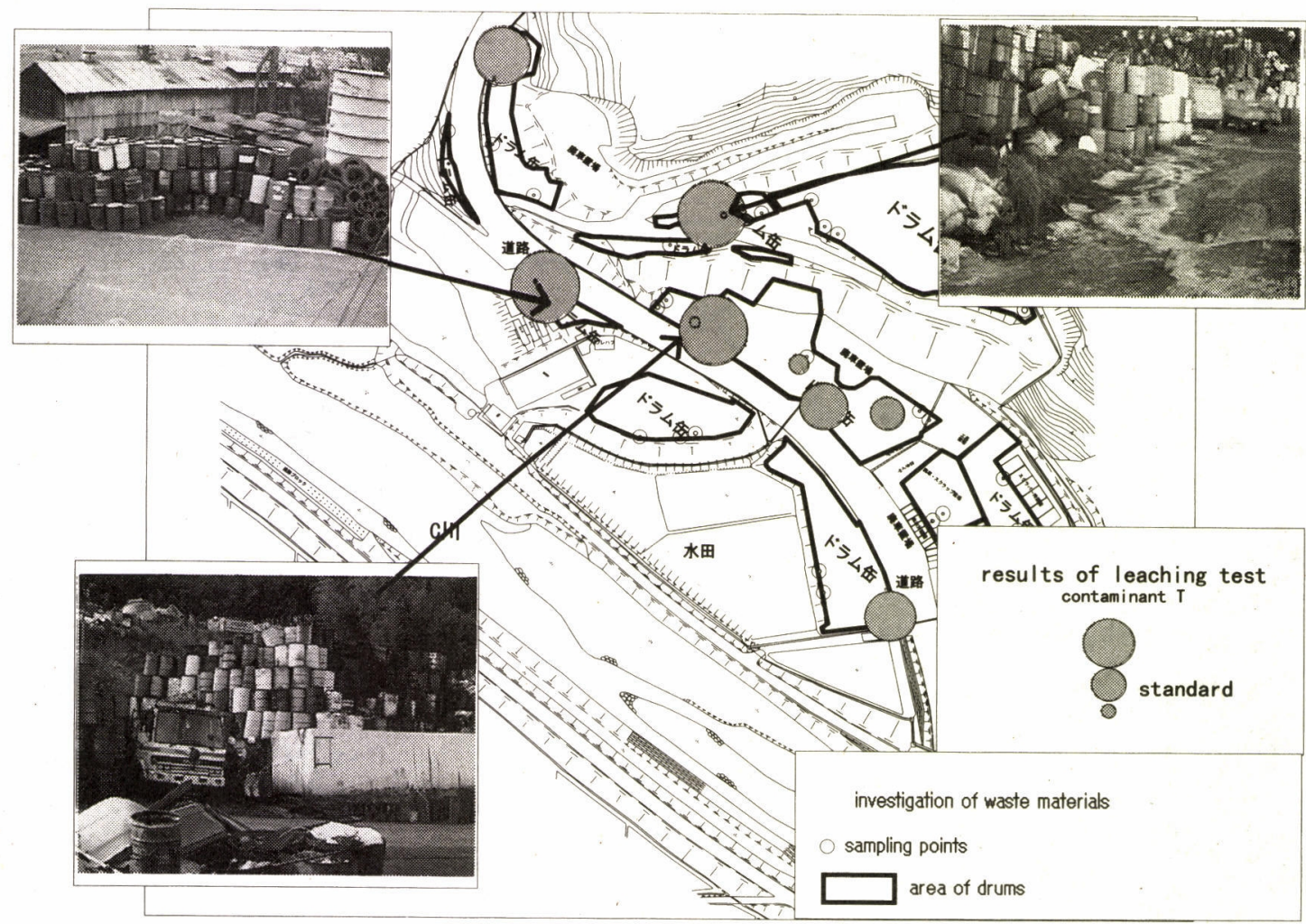

This figure shows sampling points $(O)$ and results of leaching test of waste materials : contaminant $\mathrm{T}$ ), and pictures of drums and contaminants leaking from drums.

Fig. 6 A demonstration of GIS in diagnostic system

として, 表流水の経路より整備すべき排水溝の位置や, 調整池等の設置場所に関しての具体的な議論が行える。 この場合，水田の箇所に調整池を作ることが検討された (画像および斜線部を参照)。そして敷地境界付近の水 （油）溜まりの画像も示すが，ここから敷地外への流出 防止を行う対策の必要性が検討された。

さらに地下水の調查結果を先に示した Fig. 5 に示す。 物質 Tが 2 ヶ所で検出された。ここで求められる情報 としては, 敷地内地下水の污染プリュームの大きさと, 敷地外の污染拡散の有無にある。現段階では污染プ リュームを表示する程, 地下水調査が十分ではないこと から, 今後敷地境界を含めた敷地内の地下水調查, モ二 タリングの必要性が, この調査結果より判断される。そ して次段階の対策として地下水の拡散防止対策を想定す る必要のあることが判断できる。その際には, 地質構造 推定図により遮水壁の深さ等を検討することができる。

このように, GIS 污染データ管理システムにより，画 面上で各地点の各種属性のデータを加工した結果を表示 できる。また今回は示すことができなかったが，長期に 及ぶ修復対策の修復履歴の保存や過去のデータとの比較 あ容易に行うことができる。

\section{3 各段階での目的, 作業内容の決定}

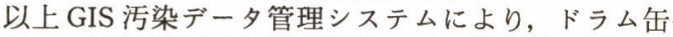
に対しては緊急的な撤去が必要なこと, 表流水に関して は敷地外への流出防止対策の必要性があること, 地下水 に関してはさらに調査・モニタリングを行い污染状況を
把握し，さらに敷地外へ拡散しないような対策を想定し ておく必要性があることを説明した。また前述しなかっ たが, 土垬に関しても撤去等の修復対策を講じる必要性 がある。そこで, 修復目標を「不適正保管現場に対して 污染水の敷地外流出, 污染拡大を未然に防ぎ, 周辺環境 のモニタリングを行うとともに，不適正保管廃棄物を速 やかに撤去し，適正な処理・処分を行う。また不適正保 管廃棄物撤去後の土垬, 地下水等の環境媒体を環境基準 まで修復すること」とし, 段階的に作業を進めることと した。

ここで 3.4 節にて述べたスコーピング時における修復 対策の選択を実践する。まずコストやその対策に必要な 時間等の制約を考虑せず，あるべき対策に関して各対策 の時間的なつながりを考慮し，さらに2.1節で述べた各 段階の対策の定義にしたがい整理する。

初期対策：ドラム缶の撤去, 表流水の敷地外流出防止 応急対策：地下水污染調查を前提とした地下水污染拡散 防止対策

恒久対策：恒久的な地下水, 土壌の修復

次に初期対策として行える対策を, 実行可能性, 施工 までの時間，コスト等を考慮し考察を加えると，

1) ドラム缶内容物の漏出による環境污染拡大の緊急 性を考えると，先にドラム缶を撤去することも考え られた。しかし， 55,000 本のドラム缶撤去はコスト (撤去, 運搬, 処理コストの積算)，施工までの時間 を考えると，安全かつ適正に処理するには初期対策 としては無理である。したがって，応急対策で運搬 


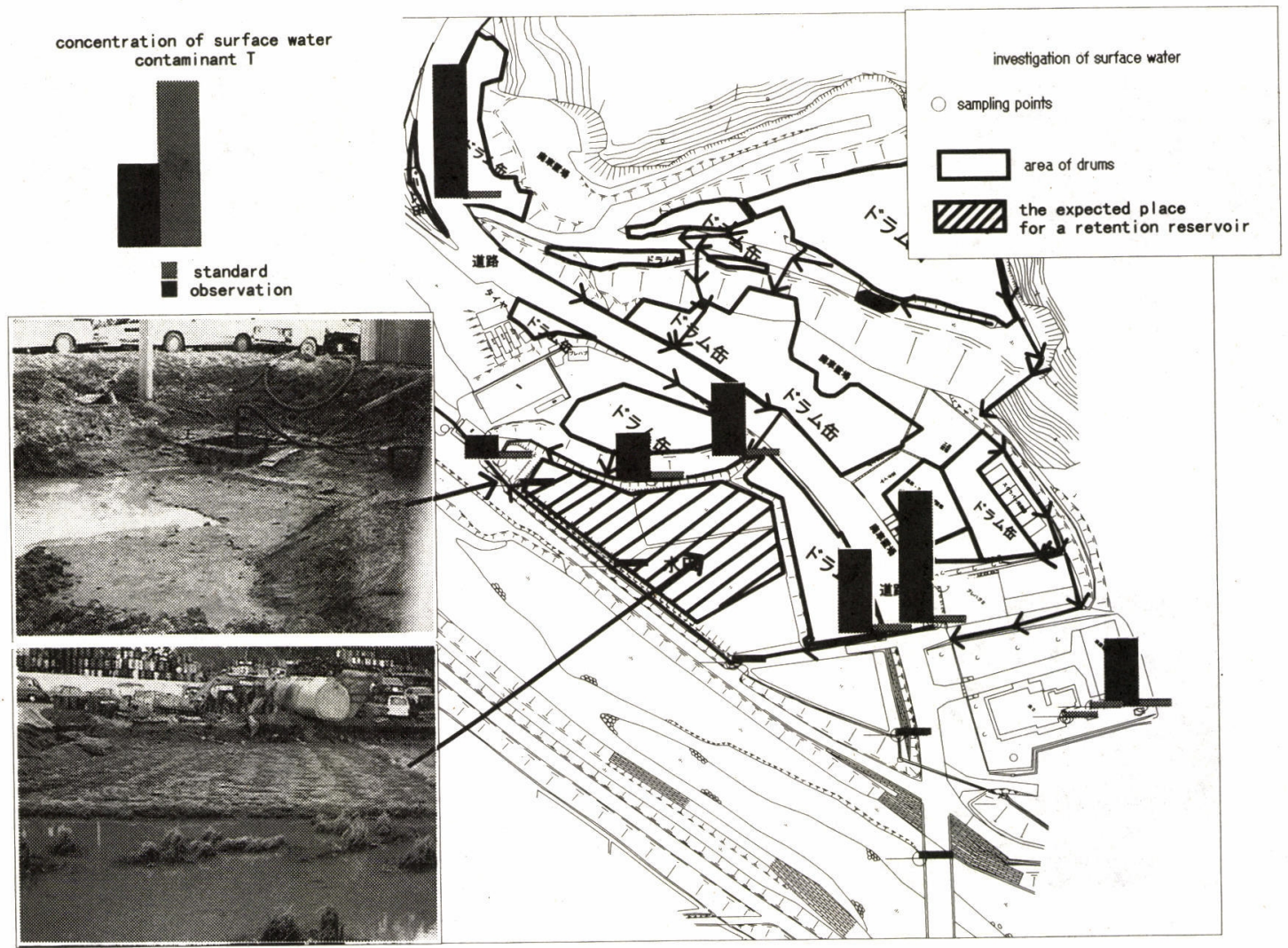

This figure shows how surface water flows, sampling points $(\bigcirc)$ and results of contaminant constituent analysis (contaminant $\mathrm{T}$ ), pictures of the boundary between the site and River $\mathrm{C}$, and the expected place for a retention reservoir.

Fig. 7 A demonstration of GIS in diagnostic system

可能なドラム缶を撤去し, 恒久対策で残りのドラム 缶と土壤を撤去することが妥当である。

2）表流水流出防止対策では, 排水溝を再整備し調整 池を設置する。水処理施設は, 応急〜恒久対策時で 設置することとし，それまでは委託処理を行う。 またスコーピングでは次段階の対策の技術のスク リーニング, 代替案の構築を行う必要がある。それ を実践する。

3) 応急対策である地下水污染拡散防止対策では, (1) 拡散防止対策無し, (2) バリア井戸のみ, (3) 遮水壁之 揚水処理の 3 つの代替案が予備的に構築された。 よって, 調査結果に基づいて, まず対策の必要性を 判断する必要がある。そして拡散防止対策を行うと すれば，バリア井戸のみでいいのか，それと屯遮水 壁を施工する必要があるのか, またバリア井戸の位 置や遮水壁の大きさ, 深さを検討する必要が生じる。 したがって, これらの判断を行うための調査デー夕, あるいは地下水シミュレーションを行うためのデー 夕が必要となる。以上のように, 応急対策としての 対策の技術をスクリーニングしておくことで, 逆に 対策側から調查項目を検討することが可能である。

4) また恒久対策に関しては, 土埣, 地下水処理が中 心なので, 地下水揚水処理あるいは原位置バイオレ メディエーションを想定する。ただし，今後追加情 報次第では, あう一度スクリーニングをやり直す。 以上のように，スコーピングにおいて污染状況全体を
見極め, 緊急度の高い部分を抽出し, コスト, 時間, 法 律等の制約により初期対策から恒久対策までおおよその 時間軸に注目して計画を構築すること, すなわち浄化構 想計画を構築するすることが重要である。また予め次段 階の修復技術を想定することによって, 必要な調査デー 夕やその調査の目的が一層明らかになり, 調查の後戻り を防ぐことができることを示した。

最後に, 最終的に決定された各段階における作業内容 を以下に示す。

初期対策：表流水の流出防止対策

応急対策：撤去可能なドラム缶の撤去・運搬・処理処分, 表流水流出防止対策 (雨水の場内流入防止), 地下水 拡散防止対策（調査，モニタリングあ含む）

恒久対策 : 残りのドラム缶の撤去・運搬・処理処分, 敷 地内の土壌・地下水修復対策

\section{5. 結 論}

診断修復システムを構築し, 実際の污染現場に適用す ることで得られた成果をまとめる。

1) 廃棄物に起因する土㙴・地下水污染が従来の事業 系の土壤・地下水污染と異なる点を示した上で, 廃 裹物に起因する土壌・地下水污染の修復対策フロー を提案した。特に廃棄物の場合は, 污染源リスクを 把握した上で, 緊急度や優先度に応じた対策を段階 的に行う必要性のあることを示した。 
2) その修復対策フローにおいて, 初期対策, 応急対 策, 恒久対策の 3 段階を想定することを提案した。 段階的に対策や調查を行うことにより, 調查の目的 が明確になり, また調査の後戻りを防止することが 期待できることから, 修復対策の効率化の可能性の あることを示唆した。

3 ）污染現場に対しまず全体を見渡し，問題点を明ら かにするプロセスであるスコーピングの概念を新た に導入し，本研究でその手順を提案した。さらに修 復対策を円滑に推進するためにはスコーピングを行 い, その中で浄化構想計画を策定することの重要性 を示した。

4） GISを用いた污染データ管理システムを用いるこ とにより，調査データの一元管理，污染状況のグラ フィカルな表現ができ, かつ修復内容の検討, 必要 な調查項目の検討が行えることを示した。GIS は土 壤・地下水污染対策の計画策定に対する有効なッー ルである。

今後は, 本研究で提案した診断修復システムに関して, シミュレーション部分, 修復方法の設計の部分の完成に 向けて作業を進める予定である。

[謝辞]

本研究を行うにあたってご協力頂いた $\mathrm{F}$ 県生活 環境部廃裹物対策課, 廃棄物研究財団の方々に深く 感謝致します。そして CDR 研究会のメンバーの 方々にあ深く感謝致します。

\section{至考献}

1）たとえば, 坂本弘道 : 廃棄物処理法の改正について, 廃棄物学会誌, Vol. 8, No. 5, pp. 352-361（1997）

2）厚生省：報道発表資料，一般廃棄物処分場における処 理の適正化について (1998.3. 5)

3）噮境庁：土壌・地下水污染の調查・対策指針の策定に ついて, いんだすと, Vol. 10, No. 1, pp. 56-66(1995)

4) 環境庁水質保全局: 土壤・地下水污染に係わる調查・ 対策指針運用基準 (1999.1)

5 ） (社) 土壌環境センター, 第 5 調查研究部会 : 最新の各種 污染土壤・地下水浄化プロセスの適用性の調查研究報 告書 (1998)

6) Office of Emergency and Remedial Response, U S. EPA : Guidance for Conducting Remedial Investigation and Feasibility Studies Under CERCLA, $\mathrm{EPA} / 540 / \mathrm{G}-89 / 004$ (1989)

7 ）加藤一郎, 森島昭夫, 大塚 直, 柳憲一郎 : 土䇎污染之 企業の責任, 安田火災海上保険 (激) 安田総合研究所 編, 有斐閣, pp. 83-124（1996）

8 ）島津康男：市民からの環境アセスメント一参加と実践 のみち, NHK ブックス, pp. 75-82（1997）

9）古市 徹, 生村隆司, 寺尾 康：廃棄物の不適正保管に 起因する土埕・地下水污染の診断システムと数值シ ミュレーションの役割, 地下水学会誌, Vol. 40, No. 2, pp. $133-144$ (1998)

10) Office of Emergency and Remedial Reponse, U. S. EPA : Community Relations in Superfund: A Handbook, EPA/ 540/R- 92/009 (1992)

\title{
Development of a Diagnostic System for Soil and Groundwater Contamination and its Application to the Inappropriate Storage Sites
}

\author{
Tohru Furuichi*, Kazuei Ishii*, Yasushi Terao** and Kanetoshi Morishita*** \\ * Graduate School of Engineering Hokkaido University \\ ** KUBOTA Corporation \\ *** TOWA KAGAKU Co., Ltd.
}

'Correspondence should be addressed to Tohru Furuichi :

(W8, N13, Sapporo-city 060-8628 Japan)

\begin{abstract}
A recent serious environmental issue has been soil and groundwater contamination caused by waste materials. However in actuality, many local governments in Japan are experiencing trouble with development of plans to restore contaminated sites, because they have no methodology. Therefore, establishment of a methodology and procedure for investigation and remediation of contaminated sites is required. In this paper, 1) we proposed a flowchart of countermeasures for soil and groundwater contamination caused by waste materials in Japan; 2) we introduced scoping into the countermeasures and showed the importance of developing a plan of basic remedial strategies; and 3 ) we developed a diagnostic system that supported the development of an investigation plan, futhermore, by applying the diagnostic system to an actual inappropriate storage site, we proposed some remedial alternatives for contaminated sites, and we showed that the data management system with the Geographic Information System (GIS), which was part of the diagnostic system, was a very effective tool in planning the basic remedial strategies.
\end{abstract}

Key words : waste materials, soil and groundwater contamination, diagnostic system, geographic information system (GIS), scoping 